\title{
Nephroprotective Effect of the Leaves of Aloe barbadensis (Aloe Vera) against Toxicity Induced by Diclofenac Sodium in Albino Rabbits

\author{
A Iftikhar ${ }^{1}$, IJ Hasan ${ }^{1}$, M Sarfraz $^{1}$, L Jafri ${ }^{2}$, MA Ashraf ${ }^{3}$
}

\begin{abstract}
Background: The present study was designed to evaluate the nephroprotective effect of the leaves of Aloe barbadensis against toxicity induced by diclofenac sodium in albino rabbits.

Subjects and Method: Thirty-six healthy albino rabbits were randomly divided into six groups each with six animals. Group 1 served as the untreated control, group 2 was treated only with diclofenac sodium, group 3 with the nephroprotective drug silymarin and groups 4, 5, and 6 were treated with different doses of Aloe barbadensis, ie $200 \mathrm{mg} / \mathrm{kg}$, $400 \mathrm{mg} / \mathrm{kg}$ and $600 \mathrm{mg} / \mathrm{kg}$, respectively after being treated with diclofenac sodium. Blood samples were collected after every five days up to fifteen days. Haematological and histopathological parameters were determined by using diagnostic kits.

Results: Results of haematological studies showed that use of the powder of Aloe barbadensis normalized the level of different factors eg, white blood cells (WBCs), red blood cells (RBCs), platelet count, packed cell volume (PCV), mean cell volume (MCV) and haemoglobin (Hb) values. Histopathological studies showed that Aloe barbadensis ameliorated pyknotic nuclei in the renal epithelial cells and reduced oxidative stress by increasing the level of catalase and decreasing malondialdehyde (MDA) level. Conclusion: These results have shown that Aloe barbadensis can normalize oxidative stress and can be used as an effective nephroprotective agent against drug-induced nephrotoxicity.
\end{abstract}

Keywords: Aloe barbadensis, diclofenac sodium, nephrotoxicity

\section{Efecto Nefroprotector de las Hojas de Aloe barbadensis (Aloe Vera) Frente a la Toxi- cidad Inducida por el Diclofenaco de Sodio en Conejos Albinos}

\author{
A Iftikhar ${ }^{1}$, IJ Hasan $^{1}$, M Sarfraz 1 , L Jafri², MA Ashraf ${ }^{3}$
}

\begin{abstract}
RESUMEN
Antecedentes: El presente estudio fue diseñado a fin de evaluar el efecto nefroprotector de las hojas de Aloe barbadensis frente a la toxicidad inducida por el diclofenaco sódico en conejos albinos.

Sujetos y método: Treinta y seis conejos albinos sanos fueron divididos aleatoriamente en seis grupos, cada uno con seis animales. El grupo 1 sirvió como control sin tratamiento, el grupo 2 fue tratado sólo con diclofenaco sódico, y el grupo 3 con silimarina-un medicamento nefroprotector. Los grupos 4, 5 y 6 fueron tratados con diferentes dosis de Aloe barbadensis, a saber, $200 \mathrm{mg} / \mathrm{kg}$, $400 \mathrm{mg} / \mathrm{kg}$ y $600 \mathrm{mg} / \mathrm{kg}$, respectivamente, después de ser tratados con diclofenaco sódico. Se recogieron muestras de sangre después de cada cinco días, hasta quince días. Los parámetros hematológicos e histopatológicos se determinaron mediante el uso de kits de diagnóstico.

Resultados: Los resultados de los estudios hematológicos mostraron que el uso del polvo de Aloe barbadensis normalizó el nivel de los diferentes factores, tales como glóbulos blancos (GB), glóbulos rojos (GR), recuento de pla-
\end{abstract}

From: ${ }^{1}$ Institute of Pharmacy, Physiology and Pharmacology, University of Agriculture, Faisalabad, Pakistan, ${ }^{2}$ Department of Biochemistry, Bahauddin Zakariya University, Multan, Pakistan and ${ }^{3}$ Universiti Malaysia Sabah, Kota Kinabalu, Sabah, Malaysia.
Correspondence: Dr M Sarfraz, Institute of Pharmacy, Physiology and Pharmacology, University of Agriculture, Faisalabad, Pakistan. E-mail: maliha.sarfraz@yahoo.com 
quetas, volumen celular aglomerado (VCA), volumen celular medio (MCV), y valores de hemoglobina (Hb). Los estudios histopatológicos demostraron que el Aloe barbadensis mejoró los núcleos picnóticos en las células epiteliales renales y redujo el estrés oxidativo al aumentar el nivel de catalasa y disminuir el nivel de malondialdehido (MDA).

Conclusión: Estos resultados han demostrado que el Aloe barbadensis puede normalizar el estrés oxidativo y utilizarse como un agente nefroprotector eficaz contra la nefrotoxicidad inducida por medicamentos.

Palabras claves: Aloe barbadensis, diclofenaco sódico, nefrotoxicidad

West Indian Med J 2015; 64 (5): 463

\section{INTRODUCTION}

Nephrotoxicity is actually the lethal effect of some materials including both noxious substances and medications on the kidney. These materials are known as nephrotoxins. Among nephrotoxins, drugs are the leading cause of nephrotoxicity. These drugs produce their poisonous effects by one or more common pathogenic mechanisms, which may include altered intraglomerular haemodynamics, tubular cell toxicity, inflammation, crystal nephropathy and rhabdomyolysis (1).

Diclofenac sodium (Voltaren) is the most significant and extensively used non-steroidal anti-inflammatory drug (NSAID). It is a highly used pharmaceutical product worldwide. It is a well-known member of the acetic acid family of NSAIDs. The principal mechanism of action of traditional (t) NSAIDs and NSAIDs selective for cyclooxygenase-2 (COX-2; named coxibs) is the inhibition of COX-2dependent prostaglandin $\mathrm{E}_{2}$ (PGE2). Diclofenac sodium is used to reduce inflammation and pain associated with arthritis, osteoarthritis and spondylitis. It is rapidly metabolized mainly by hepatic hydroxylation and subsequent conjugation (2).

Aloe vera (Aloe barbadensis L) is a plant from the lily family that possesses therapeutic and antioxidant properties. Extracts from aloe vera leaves are widely used in skin care products, and recently in health drinks and supplements (3). Aloe barbadensis is used in the traditional medicine of many cultures. It has been used for many years for topical treatment of skin injuries (including wounds and irritations) and as a key ingredient in cosmetic formulations. A barbadensis has also been used in the treatment of gastrointestinal problems (constipation and ulcers), arthritis and headaches (4).

Clinical evaluations have shown that the pharmacologically active components are concentrated in both the gel and rind of Aloe vera leaves. Aloe vera leaves contain phytochemicals eg acetylated mannans, polymannans, anthraquinone C-glycosides, anthrones, anthraquinones and various lectins. These chemicals retain therapeutic and antioxidant properties.

Keeping in view the medical importance of $A$ barbadensis, the nephroprotective effect of the leaves of $A$ barbadensis was determined in albino rabbits with nephrotoxicity induced by diclofenac sodium.

\section{SUBJECTS AND METHODS}

Thirty-six adult albino rabbits of either gender weighing about 1200 to $1500 \mathrm{~g}$ were purchased from a local market in Faisalabad, Pakistan. The rabbits were housed in individual iron cages at room temperature $\left(26^{\circ} \mathrm{C}\right)$ with a $12 / 12$-hour period of light/dark in the animal room of the Department of Physiology and Pharmacology, University of Agriculture, Faisalabad. After seven days, rabbits were randomly divided into six separate groups: normal control, treated control on diclofenac sodium, treated control on standard nephroprotective drug (silymarin) and three treated groups on different doses of aloe vera. Each group comprised six rabbits.

The rabbits were provided with seasonal fodder until the completion of the experiment. The feed was made available twice a day in the morning and evening; drinking water was available ad libitum. Except for the normal control group that was kept on seasonal fodder, the rest of the groups were provided with diclofenac sodium for 15 days.

\section{Drugs}

Nephrotoxic drug: Diclofenac sodium at dose rate of $50 \mathrm{mg} / \mathrm{kg}$, manufactured by Abbott Laboratories Pakistan Ltd.

Nephroprotective drug: standard drug (silymarin) at dose rate of $150 \mathrm{mg} / \mathrm{kg}$, manufactured by Searl Pakistan (SPL) Ltd.

\section{Plant}

The leaves of $A$ barbadensis were collected and identified for authentication by the Department of Botany, University of Agriculture, Faisalabad.

The powder of $A$ barbadensis leaves was prepared from $A$ barbadensis leaf gel. Mature, healthy and fresh leaves of $A$ barbadensis having a length of approximately 75 to $90 \mathrm{~cm}$ were washed with fresh water. The leaves were cut transversely into pieces. The thick epidermis was selectively removed. The solid gel in the centre of the leaf was homogenized. The resulting mucilaginous, thick and straw coloured homogenate was lyophilized. Then the lyophilized sample was extracted using 95\% ethanol. The filtrate was collected and evaporated to dryness under reduced pressure in a rotary evaporator. The residue was stored in dry sterilized small containers at $4{ }^{\circ} \mathrm{C}$ until further use. This was administered at the dose rate of $200 \mathrm{mg} / \mathrm{kg}, 400 \mathrm{mg} / \mathrm{kg}$ and $600 \mathrm{mg} / \mathrm{kg}$ to treat groups 4,5 , and 6 for $0-15$ days. 


\section{Collection of blood samples}

Blood samples were collected from 0-15 days at five-day intervals from the jugular vein of rabbits. The samples were allowed to clot for 20 minutes at refrigeration temperature and then centrifuged at $4000 \mathrm{rpm}$ for five minutes. Serum was separated and stored at freezing temperature $\left(-20^{\circ} \mathrm{C}\right)$ until analysis.

\section{Study parameters}

The serum samples were taken to determine the functions of the kidney. These parameters include blood urea nitrogen (BUN), creatinine, haematological parameters (platelet count, red blood cell $[\mathrm{RBC}]$ count, white blood cell $[\mathrm{WBC}]$ count, packed cell volume [PCV], mean corpuscular haemoglobin $[\mathrm{MCH}]$, mean cell volume $[\mathrm{MCV}]$ and mean corpuscular haemoglobin concentration $[\mathrm{MCHC}]$ ) by using standard methods, and the kidneys were identified and carefully dissected out for histopathological examination (5). Health biomarkers were performed to determine the antioxidant level of the body. These include total oxidant status (TOS), total antioxidant status (TAS), malondialdehyde (MDA) and catalase by following standard protocols described by Erel $(6,7)$ and Ohkawa et al (8). Catalase activity was determined by using the method of Goth (9).

\section{Statistical analysis}

In each group, the significance of the difference between pretreated and post-treated groups was tested by using two-way analysis of variance (10) followed by Duncan's multiple range test (11).

\section{RESULTS}

The blood samples were taken after each five-day interval for the determination of biochemical parameters like serum BUN and creatinine. Diclofenac sodium produced significant increase $(p<0.05)$ in BUN and creatinine $(48.65 \pm 8.63$ and 1.80 \pm 0.18 ) when compared to Aloe barbadensis treated groups, particularly at dose rate of $600 \mathrm{mg} / \mathrm{kg}(24.60 \pm 1.44$ and 1.02 $\pm 0.04)$. Thus, treatment with Aloe barbadensis resulted in significant decrease $(p<0.05)$ in BUN and creatinine levels (Table 1).

\section{Health biomarkers}

Diclofenac sodium-induced oxidative stress in the kidneys was indirectly determined by serum MDA level and catalase activity. Diclofenac induced oxidative stress in the kidneys, resulted in significant increase $(p<0.05)$ in the level of MDA $(9.425 \pm 2.375)$ in serum and decrease in catalase activity $(29.505 \pm 2.345)$. Aloe barbadensis significantly $(p<0.05)$ reduced the level of MDA (6.610 \pm 0.440$)$ and increased catalase (48.582 \pm 7.977$)$, resulting in increased antioxidant activity (Table 2).

\section{Haematology}

Haematological parameters such as haemoglobin ( $\mathrm{Hb} ; \%)$, PCV (\%), platelet count $\left(/ \mathrm{m}^{3}\right), \mathrm{RBC}$ count $\left(\mathrm{mill} / \mathrm{m}^{3}\right)$, WBC count $\left(/ \mathrm{m}^{3}\right), \mathrm{MCH}$ (picogram), MCHC (\%) and MCV (fL) were estimated after each five-day interval for 15 days. The results indicated significant changes in these values due to treatment with the drug (diclofenac sodium) and Aloe barbadensis (Table 3 ).

Table 1: Results of blood urea nitrogen (BUN) and creatinine levels

\begin{tabular}{lcc}
\hline Parameters & BUN (mg/dL) & Creatinine (mg/dL) \\
\hline Control group & $22.00 \pm 0.23^{\mathrm{c}}$ & $1.15 \pm 0.04^{\mathrm{c}}$ \\
Nephrotoxic drug (diclofenac sodium $50 \mathrm{mg} / \mathrm{kg})$ & $48.65 \pm 8.63^{\mathrm{a}}$ & $1.80 \pm 0.18^{\mathrm{a}}$ \\
Nephroprotective drug (silymarin $150 \mathrm{mg} / \mathrm{kg})$ & $22.00 \pm 0.23^{\mathrm{c}}$ & $1.15 \pm 0.04^{\mathrm{c}}$ \\
Aloe barbadensis $200 \mathrm{mg} / \mathrm{kg}$ & $35.80 \pm 4.61^{\mathrm{b}}$ & $1.51 \pm 0.16^{\mathrm{b}}$ \\
Aloe barbadensis $400 \mathrm{mg} / \mathrm{kg}$ & $30.28 \pm 2.74^{\mathrm{bc}}$ & $1.26 \pm 0.02^{\mathrm{bc}}$ \\
Aloe barbadensis $600 \mathrm{mg} / \mathrm{kg}$ & $24.60 \pm 1.44^{\mathrm{c}}$ & $1.02 \pm 0.04^{\mathrm{c}}$ \\
\hline a, b, : mean values within a column not bearing a common superscript differ significantly $(p<$ \\
$0.05)$
\end{tabular}

Table 2: Results of health biomarkers

\begin{tabular}{lcccc}
\hline Parameters & TOS $(\boldsymbol{\mu m o l} / \mathbf{L})$ & TAC $(\mathbf{m m o l} / \mathbf{L})$ & MDA $(\mathbf{n m o l} / \mathbf{L})$ & Catalase $(\mathbf{k U} / \mathbf{L})$ \\
\hline $\begin{array}{l}\text { Control group } \\
\text { Nephrotoxic drug (diclofenac sodium }\end{array}$ & $4.04 \pm 0.17^{\mathrm{bc}}$ & $0.50 \pm 0.005^{\mathrm{ab}}$ & $5.80 \pm 0.01^{\mathrm{c}}$ & $36.41 \pm 0.22^{\mathrm{a}}$ \\
$\begin{array}{l}\text { 5 } \mathrm{mg} / \mathrm{kg} \text { ) } \\
\text { Nephroprotective drug }\end{array}$ & $5.31 \pm 1.17^{\mathrm{a}}$ & $0.38 \pm 0.13^{\mathrm{b}}$ & $9.42 \pm 2.37^{\mathrm{a}}$ & $29.50 \pm 2.34^{\mathrm{b}}$ \\
(silymarin $150 \mathrm{mg} / \mathrm{kg})$ & $3.63 \pm 0.18^{\mathrm{bc}}$ & $0.69 \pm 0.03^{\mathrm{ab}}$ & $6.49 \pm 0.21^{\mathrm{bc}}$ & $39.08 \pm 0.58^{\mathrm{a}}$ \\
Aloe barbadensis $200 \mathrm{mg} / \mathrm{kg}$ & $3.37 \pm 0.13^{\mathrm{b}}$ & $0.69 \pm 0.05^{\mathrm{ab}}$ & $7.23 \pm 0.78^{\mathrm{b}}$ & $44.42 \pm 2.81^{\mathrm{a}}$ \\
Aloe barbadensis $400 \mathrm{mg} / \mathrm{kg}$ & $3.01 \pm 0.02^{\mathrm{b}}$ & $0.85 \pm 0.01^{\mathrm{a}}$ & $7.33 \pm 0.04^{\mathrm{b}}$ & $41.97 \pm 0.70^{\mathrm{a}}$ \\
Aloe barbadensis $600 \mathrm{mg} / \mathrm{kg}$ & $3.02 \pm 0.45^{\mathrm{b}}$ & $0.85 \pm 0.04^{\mathrm{a}}$ & $6.61 \pm 0.44^{\mathrm{bc}}$ & $48.58 \pm 7.97^{\mathrm{a}}$ \\
\hline
\end{tabular}

TOS: total oxidant status; TAC: total antioxidant capacity; MDA: malondialdehyde

${ }^{\mathrm{a}, \mathrm{b}} \mathrm{c}$ : mean values within a column not bearing a common superscript differ significantly $(p<0.05)$ 
Table 3: Results of haematological parameters

\begin{tabular}{|c|c|c|c|c|c|c|}
\hline Parameters & Control group & $\begin{array}{l}\text { Diclofenac } \\
\text { sodium } \\
50 \mathrm{mg} / \mathrm{kg}\end{array}$ & $\begin{array}{r}\text { Silymarin } \\
150 \mathrm{mg} / \mathrm{kg}\end{array}$ & $\begin{array}{c}\text { Aloe } \\
\text { barbadensis } \\
200 \mathrm{mg} / \mathrm{kg}\end{array}$ & $\begin{array}{c}\text { Aloe } \\
\text { barbadensis } \\
400 \mathrm{mg} / \mathrm{kg}\end{array}$ & $\begin{array}{c}\text { Aloe } \\
\text { barbadensis } \\
600 \mathrm{mg} / \mathrm{kg}\end{array}$ \\
\hline Platelet count $\left(/ \mathrm{m}^{3}\right)$ & $43175 \pm 6.06^{\mathrm{ab}}$ & $158863 \pm 77287^{d}$ & $432083 \pm 7309^{c}$ & $15863 \pm 77287^{b}$ & $397375 \pm 17560^{\mathrm{a}}$ & $517792 \pm 350^{\mathrm{ab}}$ \\
\hline $\mathrm{RBC}$ count (mill $\left./ \mathrm{m}^{3}\right)$ & $6.58 \pm 0.10^{\mathrm{a}}$ & $3.91 \pm 0.99^{\mathrm{c}}$ & $5.18 \pm 0.1^{\mathrm{bc}}$ & $5.44 \pm 0.16^{\mathrm{ab}}$ & $5.67 \pm 0.16^{\mathrm{ab}}$ & $6.95 \pm 0.12^{\mathrm{a}}$ \\
\hline WBC count $\left(/ \mathrm{m}^{3}\right)$ & $6854.18 \pm 221.26^{\mathrm{ab}}$ & $5887.48 \pm 254.17^{b}$ & $6750.00 \pm 119.80^{\mathrm{ab}}$ & $7195.8 \pm 331^{\mathrm{ab}}$ & $5741.65 \pm 378.14^{\mathrm{b}}$ & $8095.85 \pm 799^{a}$ \\
\hline PCV $(\%)$ & $43.43 \pm 0.73^{\mathrm{a}}$ & $28.6 \pm 5.63^{b}$ & $42.13 \pm 0.5^{\mathrm{a}}$ & $41.55 \pm 0.81^{\mathrm{a}}$ & $42.72 \pm 1.07^{\mathrm{a}}$ & $45.86 \pm 1.58^{\mathrm{a}}$ \\
\hline $\mathrm{Hb}(\mathrm{g} / \mathrm{dL})$ & $21.31 \pm 0.34^{\mathrm{b}}$ & $19.4 \pm 0.76^{c}$ & $21.1 \pm 0.27^{b}$ & $21.0 \pm 0.24^{b}$ & $21.13 \pm 0.41^{\mathrm{b}}$ & $23.02 \pm 0.58^{\mathrm{a}}$ \\
\hline $\mathrm{MCH}(\mathrm{pg})$ & $21.31 \pm 0.34^{b}$ & $19.4 \pm 0.76^{c}$ & $21.1 \pm 0.27^{b}$ & $21.0 \pm 0.25^{b}$ & $21.13 \pm 0.4^{\mathrm{b}}$ & $23.00 \pm 0.59^{\mathrm{a}}$ \\
\hline $\mathrm{MCHC}(\%)$ & $30.74 \pm 0.12^{\mathrm{a}}$ & $28.9 \pm 0.79^{b}$ & $30.7 \pm 0.07^{\mathrm{a}}$ & $31.57 \pm 0.38^{\mathrm{a}}$ & $31.54 \pm 0.51^{\mathrm{a}}$ & $32.11 \pm 0.52^{\mathrm{a}}$ \\
\hline MCV (fL) & $76.30 \pm 0.39^{\mathrm{a}}$ & $65.2 \pm 1.04^{\mathrm{c}}$ & $76.2 \pm 1.2^{\mathrm{ab}}$ & $67.4 \pm 0.62^{\mathrm{c}}$ & $71.19 \pm 1.9^{\mathrm{bc}}$ & $81.48 \pm 2.40^{\mathrm{a}}$ \\
\hline
\end{tabular}

RBC: red blood cells; WBC: white blood cells; PCV: packed cell volume; HB: haemoglobin; MCH: mean corpuscular haemoglobin; MCHC: mean corpuscular haemoglobin concentration; MCV: mean cell volume

a, b, c: mean values within a row not bearing a common superscript differ significantly $(p<0.05)$

\section{Histopathology}

Histopathological studies showed that diclofenac sodium produced necrotic changes in the kidney. The renal parenchyma of the rabbits in the toxic group (diclofenac sodium treated) showed necrotic changes indicated by pyknotic nuclei in the tubular epithelial cells. Mild to moderate degree of congestion was present and these changes were present throughout the renal parenchyma. In the lumen of tubules, renal casts were also present (Figs. 1, 2) when compared with normal kidneys of the control group (Fig. 3).

In the silymarin treated group, renal parenchyma was normal in appearance, however, a mild degree of pyknotic changes was present in the tubular epithelial cells. A mild to moderate degree of congestion was also present, indicating partial amelioration with silymarin (Figs. 4, 5).

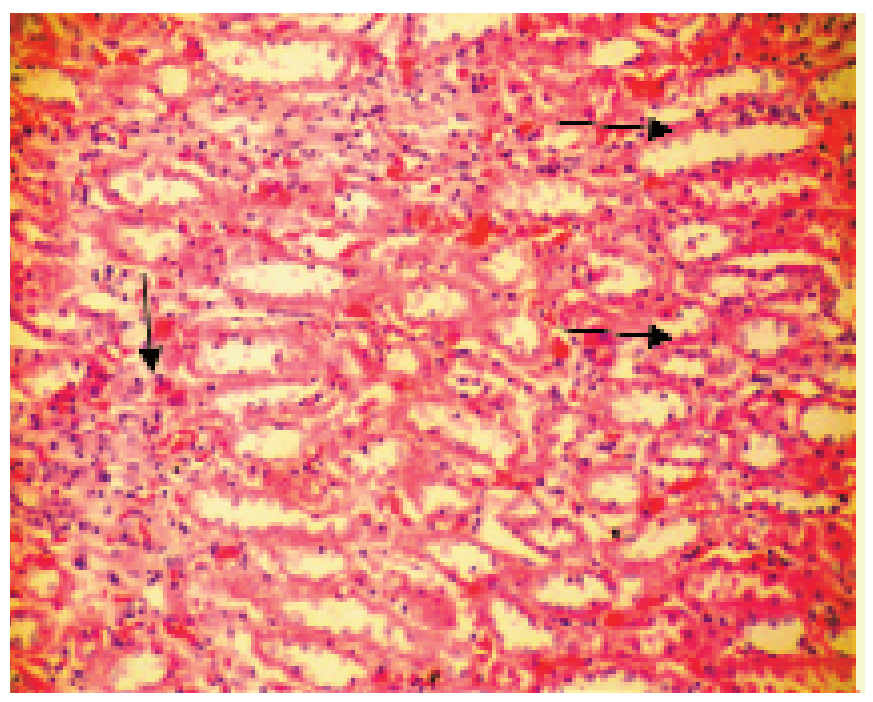

Fig. 1: Photomicrograph of kidney of the toxic group (diclofenac sodium $50 \mathrm{mg} / \mathrm{kg}$ ) showing pyknotic nuclei in tubular epithelial cells and congestion in normal renal parenchyma (H\&E staining 200×).

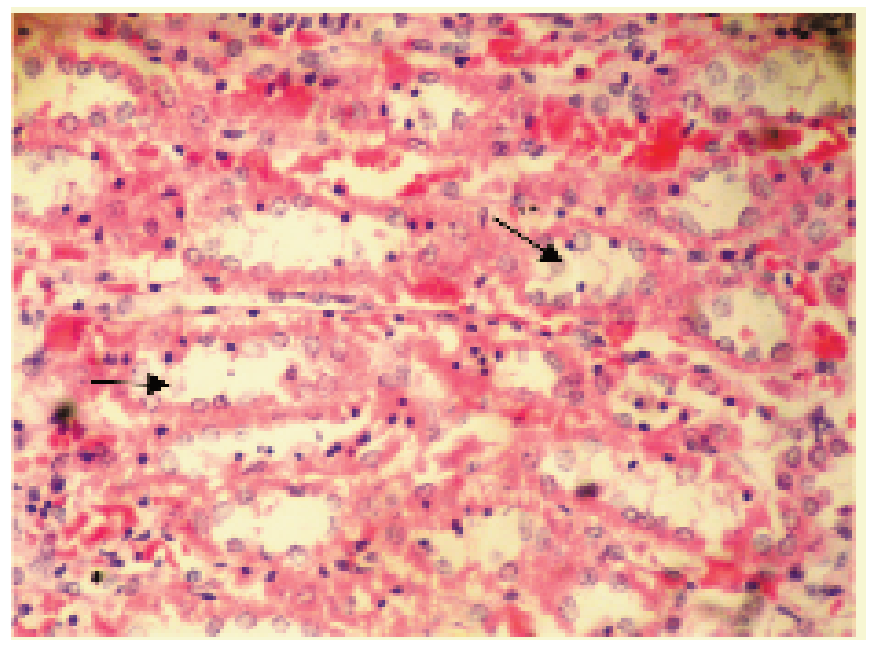

Fig. 2: Photomicrograph of kidney of toxic group (diclofenac sodium 50 $\mathrm{mg} / \mathrm{kg}$ ) showing tubular epithelial cell necrosis in renal parenchyma (H\&E staining 400×).

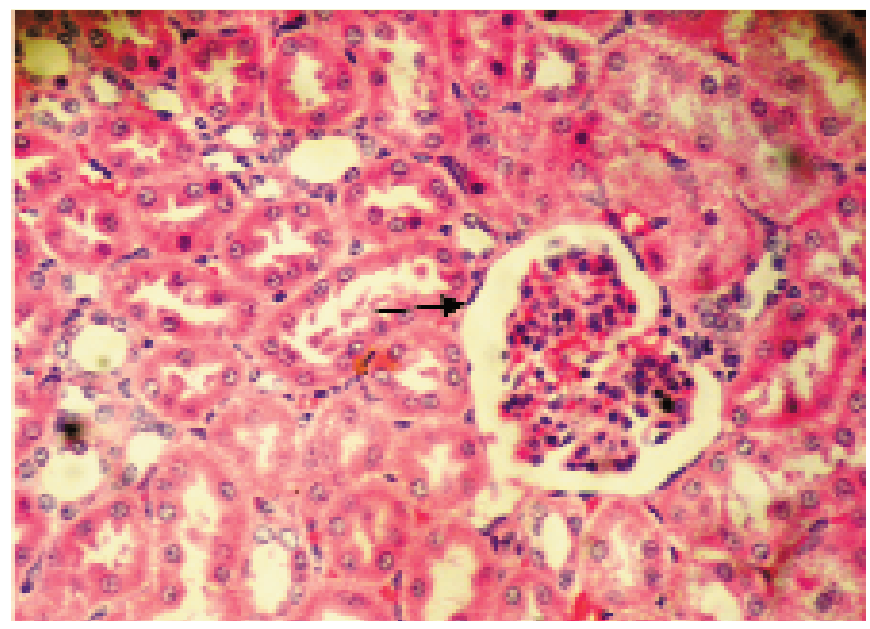

Fig. 3: Photomicrograph of kidney of the control group showing normal renal parenchyma (H\&E staining $400 \times)$. 


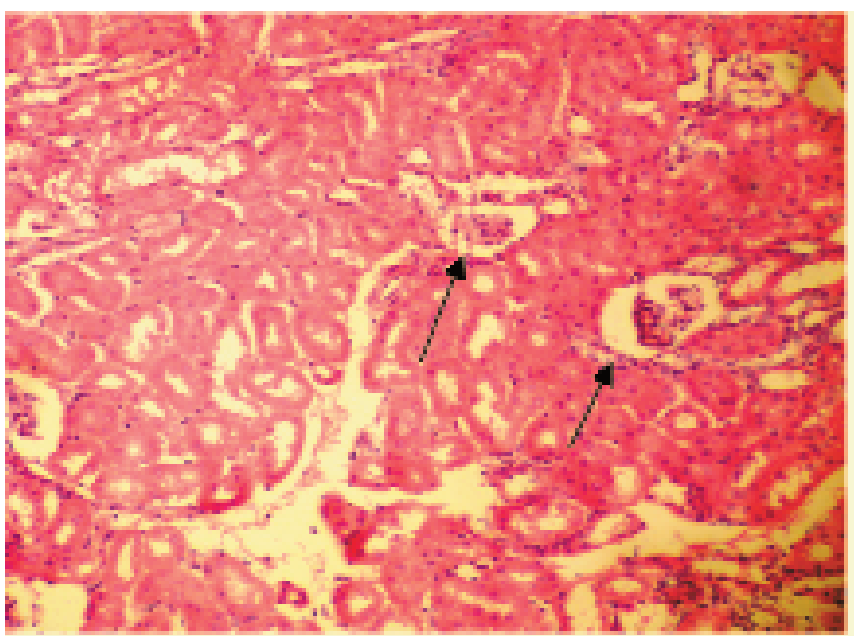

Fig. 4: Photomicrograph of kidney of the silymarin treated group showing normal renal parenchyma with few pyknotic nuclei (H\&E staining $200 \times)$.

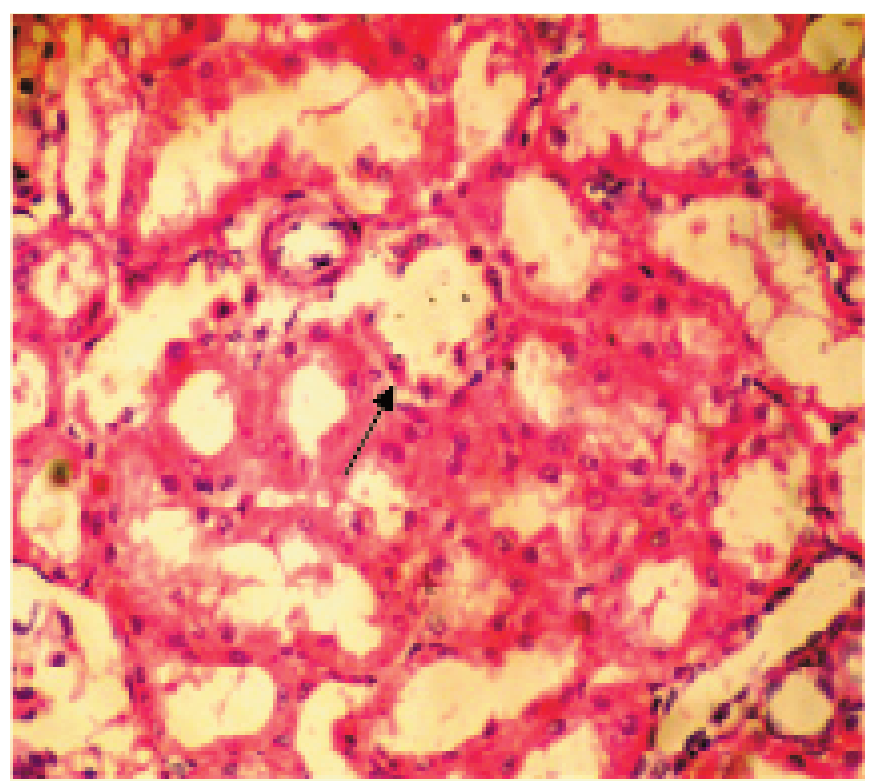

Fig. 5: Photomicrograph of kidney of $A$ barbadensis treated group (600 $\mathrm{mg} / \mathrm{kg}$ ) showing normal renal parenchyma (H\&E staining 400×).

\section{DISCUSSION}

Different physiologic and chemical changes play important roles in increasing the exposure of the kidney to nephrotoxicity. A research study has proven that diclofenac sodium causes the inhibition of both COX1 and COX2 (12) and plays an important role in causing nephrotoxicity. Blood urea nitrogen is controlled by the metabolic rate of proteins and the rate of removal of urea nitrogen. Results in the present study have shown that administration of diclofenac sodium to rabbits up to 15 days resulted in significant increase $(p<0.05)$ in the level of BUN and creatinine $(48.65 \pm 8.63,1.80 \pm 0.18)$ as compared to the normal control group $(22.00 \pm 0.23,1.15 \pm 0.04)$.

Administration of $A$ barbadensis at different doses ie 200 $\mathrm{mg} / \mathrm{kg}, 400 \mathrm{mg} / \mathrm{kg}$ and $600 \mathrm{mg} / \mathrm{kg}$ along with diclofenac sodium significantly decreased the level of BUN and serum creatinine $(24.60 \pm 1.44,1.02 \pm 0.04)$ as compared to the toxic control group $(48.65 \pm 8.63,1.80 \pm 0.18)$. A research study supports these results in which administration of a combined mixture of unpeeled lentil seeds, apple (fruits) and parsley (vegetable) in rats suffering from hyperlipidaemia significantly $(p<0.05)$ decreased the level of BUN and creatinine as compared to the hyperlipidaemic group (13). These results are also in accordance with another research study in which administration of aqueous juice of purslane (Portulaca oleracea) produced antioxidant effect by decreasing the level of MDA and also by decreasing the level of BUN and creatinine as compared to the normal control group (14). According to another study, use of Hemidesmus indicus is very helpful in the treatment of aminoglycoside-induced nephrotoxicity (15). Another study has proven that use of selenium and garlic in rats resulted in a decrease in the level of BUN and creatinine as compared to the toxic control group (16). These results are parallel to another research study in which the level of BUN and creatinine was significantly $(p<0.05)$ reduced as compared to the toxic group due to the administration of ethanolic extract of the herbal plant Macrothelypteris oligophlebia in rats (17).

In the current study, the number of RBCs, WBCs, MCV and platelets was significantly $(p<0.05)$ decreased after the administration of diclofenac sodium as compared to the normal control group. Haemoglobin is an oxygen carrying metalloprotein present in RBCs. In this study, the concentrations of $\mathrm{Hb}, \mathrm{MCH}, \mathrm{MCHC}$ and PCV were significantly decreased $(p<$ $0.05)$ in diclofenac sodium treated rabbits as compared to the normal control group (Table 3).

Results of this study have proven that use of $A$ barbadensis along with diclofenac sodium produces protective effects and a significant increase $(p<0.05)$ in the RBC and WBC count. These results are parallel to some of the previous studies which have proven that use of $A$ barbadensis produced increase in the WBC count and this was due to lecithin and sugars present in A barbadensis (18). Meral et al reported an increase in WBC count due to the administration of herbal plants in mice. Their results proved that administration of extract of Nigella sativa in diabetic rabbits produced significant increase $(p<0.05)$ in the levels of WBCs, RBCs, Hb and PCV as compared to diabetic rabbits (19). Another study supports these results in which administration of a mixture of apple, parsley and lentil in rats suffering from hyperlipidaemia and hypercholesterolaemia resulted in increase in the level of WBCs, RBCs and $\mathrm{Hb}$ as compared to hyperlipidaemic values (13).

Diclofenac sodium also affects health biomarkers (TOS, TAC, MDA and catalase). In the present study, diclofenac sodium induced oxidative stress in the body and became the major cause of nephrotoxicity, which was indicated by accretion of MDA in the kidney $(9.425 \pm 2.375)$ and decreased level of catalase $(29.505 \pm 2.345)$ and antioxidant status. These results were supported by previous studies which showed an increase in the lipid peroxidation in the body by increasing the 
MDA level (20) and catalase activity was decreased (21). But due to the use of $A$ barbadensis, there appeared significant decrease in oxidative stress, an increase in the activity of catalase and a decrease in the activity of MDA. Previous studies have also shown that antioxidant properties of $A$ barbadensis decrease oxidative stress by decreasing the activity of MDA and increasing the activity of catalase (22). These results are parallel to the study by Wu et al in which use of Macrothelypteris oligophlebia rhizomes produced nephroprotective and antioxidant effects by decreasing the level of MDA and increasing the level of catalase as compared to the toxic control group (17).

Aloe barbadensis produced significant positive results at different graded doses. Photomicrographs have shown that the renal parenchyma of this group was normal. In a few places, mild to moderate degree of congestion was also present. It indicated complete amelioration with this plant. These results are parallel to one of the previous studies in which histopathological examination of different kidney sections showed that use of extracts of Petroselinum sativum, Eruca sativa and Curcuma longa herbs in gentamicin-nephrotoxic rats caused ameliorated renal tubular necrosis and increased activities of renal antioxidant enzymes in gentamicin-intoxicated rats (23). In another study, dose-related amelioration in the indices of toxicity was noted when the two higher doses of the Rhazya stricta Decne plant extract were given to gentamicin-induced nephrotoxic rats (24).

\section{CONCLUSION}

The nephroprotective effect of $A$ barbadensis has been determined in albino rabbits in whom nephrotoxicity was induced by diclofenac sodium. The results show that Aloe barbadensis can normalize the effects of oxidative stress and can be used as an effective nephroprotective agent against drug-induced nephrotoxicity.

\section{REFERENCES}

1. Palmer BF. Renal dysfunction complicating the treatment of hypertension. N Engl J Med 2002; 347: 1256-61.

2. Tang W. The metabolism of diclofenac-enzymology and toxicology perspectives. J Curr Drug Metab 2003; 4: 319-29.

3. Nindo CI, Powers JR, Tang J. Thermal properties of Aloe vera powder and rheology of reconstituted gels. J Am Soc Agric Biol Eng 2010; 53: 1193-1200.

4. Bozzi A, Perrin C, Austin S, Arcevera F. Quality and authenticity of commercial Aloe vera gel powders. J Food Chain 2007; 103: 22-33.

5. Bancroft JD, Gamble M. Theory and practice of histological techniques. $5^{\text {th }}$ ed. London: Churchill Livingstone; 2002.
6. Erel O. A novel automated direct measurement method for total antioxidant capacity using a new generation, more stable ABTS radical cation. J Clin Biochem 2004; 37: 277-85.

7. Erel $\mathrm{O}$. A new automated colorimetric method for measuring total oxidant status. J Clin Biochem 2005; 38: 1103-11.

8. Ohkawa H, Ohishi N, Yagi K. Assay for lipid peroxides in animal tissue by thiobarbituric acid reaction. Anal Biochem 1979; 95: 351-8.

9. Goth L. A simple method for determination of serum catalase and reversion of reference range. Clin Chim Acta 1991; 196: 143-51.

10. Steel RGD, Torrie JH, Dicky DA. Principles and procedures of statistics. $3^{\text {rd }}$ ed. New York: McGraw Hill; 1997.

11. Duncan DB. Multiple range and multiple F-tests. Biometrics 1955; 11: $1-42$.

12. Quiralte J, Blanco C, Delgado J, Ortega N, Alcántara M, Castillo RT et al. Challenge-based clinical patterns of 223 Spanish patients with nonsteroidal anti-inflammatory drug-induced reactions. J Investig Allergol Clin Immunol 2007; 17: 182-8.

13. Abdel-Rahim EA, El-Beltagi HS. Constituents of apple, parsley and lentil edible plants and their therapy treatments for blood picture as well as liver and kidneys functions against lipidemic disease. Electron J Environ Agric Food Chem 2010; 9: 1117-27.

14. Dkhil MA, Moniem AEA, Al-Quraishy S, Saleh RA. Antioxidant effect of purslane (Portulaca oleracea) and its mechanism of action. J Med Plant Res 2011; 5: 1589-93.

15. Kotnis MS, Patel P, Menon SN, Sane RT. Renoprotective effect of Hemidesmus indicus, a herbal drug used in gentamicin-induced renal toxicity. Nephrology 2004; 9: 142-52.

16. El-Shenawy SMA, Hassan NS. Comparative evaluation of the protective effect of selenium and garlic against liver and kidney damage induced by mercury chloride in the rats. Pharmacol Rep 2008; 60: 199-208.

17. Wu G, Cai Y, Wei H, Wei A, Xiong C, Fu W et al. Nephroprotective activity of Macrothelypteris oligophlebia rhizomes ethanol extract. Pharm Biol 2012; 50: 773-7.

18. Rehman SU, Durrani FR, Chand N, Khan RU, Rehman FU. Comparative efficacy of different schedules of administration of medicinal plants infusion on hematology and serum biochemistry of broiler chicks. ROAVS 2011; 1: 8-14.

19. Meral I, Donmez N, Baydas B, Belge F, Kanter M. Effect of Nigella sativa $L$ on heart rate and some haematological values of alloxan-induced diabetic rabbits. Scand J Lab Anim Sci 2004; 31: 49-53.

20. Hickey EJ, Raje RR, Reid VE, Gross SM, Ray SD. Diclofenac induced in vivo nephrotoxicity may involve oxidative stress-mediated massive genomic DNA fragmentation and apoptotic cell death. Free Radic Biol Med 2001; 31: 139-52.

21. Stanely Mainzen Prince P, Menon VP. Antioxidant action of Tinospora cordifolia root extract in alloxan diabetic rats. Phytother Res 2001; 15: 213-8.

22. Rajasekaran S, Sivagnanam K, Subramanian S. Antioxidant effect of aloe vera gel extract in streptozotocin-induced diabetes in rats. Pharmacol Rep 2005; 57: 90-6.

23. Shalaby MA, Hammouda AA. Nephroprotective, diuretic and antioxidant effects of some medicinal herbs in gentamicin-nephrotoxic rats. J Intercult Ethnopharmacol 2014; 3: 1-8.

24. Ali BH. The effect of treatment with the medicinal plant Rhazya stricta decne on gentamicin nephrotoxicity in rats. Phytomedicine 2002; 9: 3859. 